\title{
GADEMILJØETS DYSTRE SIDER
}

Om politi, værtshuse og spritkørsel

\section{Af Flemming BALVig}

Gademiljøet har sine dystre sider. Måske har de dystre sider endog overtaget. Gademiljøet er blevet et miljø, der skal overstås. Det er blevet til et sæt geografiske forbindelseslinier, som det gælder om at passere hurtigst muligt og undgå mest muligt. Gademiljøet er blevet et sted, man flygter fra. Et i bedste fald indholdstomt rum, i værste fald et skræmmende og utrygt kanalsystem, man desværre føler sig nødsaget til at bruge for at bevæge sig imellem de punkter i tilværelsen, hvor det egentlige liv leves.

Man må da også erkende, at gademiljøet indeholder risici. At sno sig rundt i dette miljø ved hjælp af eller uden moderne transportteknologi indebærer en trussel mod den enkeltes fysiske integritet. Man risikerer at komme til skade i dette miljø. Man risikerer midlertidigt eller varigt at få sin krop læderet, og der er næppe noget andet $\mathrm{i}$ tilværelsen der betragtes som så helligt og ukrænkeligt for den enkelte som netop den fysiske integritet.

De risici, der eksisterer for at komme fysisk til skade i gademiljøet, antager mange forskellige former, men der er to, der til stadighed tiltrækker sig særlig stor offentlig opmærksomhed.

Den ene er rumligt hovedsageligt placeret nær gadens pulserende centrum. Det er risikoen for at komme til skade i forbindelse med spritkørsel. Den anden er rumligt placeret nær gadens mindre støjende periferi. Det er risikoen for at komme til skade ved gadevold.

Ud over det fælles forankringspunkt i gademiljøet er der nogle bemærkelsesværdige lighedspunkter mellem spritkørsel og gadevold.

For det første er det problemer af nogenlunde samme størrelsesorden, i det mindste i Danmark. Hvis vi ser på de kendte og registrerede tilfælde viser en kortlægning fra 1982, at godt 1.000 sagesløse mennesker årligt fysisk kommer til skade ved gadevold (Balvig m.fl., 1986). Det er omtrent det samme antal, der kommer fysisk til skade ved spritkørsel, når vi - ligesom ved gadevolden - ser bort fra evt. skade på gerningspersonen selv. Det fremgår dog også, at det »våben « - typisk en bil - der anvendes ved spritkørsel, er farligere end det typiske »våben« ved gadevold, de bare næver. Ofrene for spritkørsel kommer alvorligere til skade. Risikoen for som uskyldigt impliceret at blive dræbt ved spritkørsel er mindst 10 gange større end risikoen for at blive dræbt ved gadevold.

For det andet er tidsrytmen for spritkørsel og gadevold den samme. Mellem halvdelen og to trediedele af såvel gadevolden som spritkørslen indtræffer mellem klokken 18 og klokken 3 om naten. Og knapt halvdelen af alle tilfælde er koncentreret til to af ugens dage, fredag og lørdag. 
For det tredje er gerningspersonerne i betydelig udstrækning rekrutteret på samme måde. Både spritkørsel og gadevold er udpræget mandsdomineret. Blandt de registrerede gerningspersoner findes kun et par procent kvinder. Begge områder er desuden ungdomsdomineret, gadevold dog i større grad end spritkørsel. Lighedspunkterne understreges af, at der blandt dømte for gadevold er relativt flere end i den øvrige befolkning, der tidligere har haft en eller flere domme for fordselslovsovertrædelser - og at der blandt dømte for spritkørsel er en forhøjet hyppighed af personer tidligere dømt for straffelovskriminalitet. Det ser ud til, at jo alvorligere tilfælde, der er tale om, jo større er denne overlapning. Man skal dog ikke overdrive disse fælles udgangspunkter i persongruppen bag spritkørsel og gadevold. Eksempelvis er det absolut set de færreste af spritkørerne, der har tidligere straffelovsdomme bag sig. I det hele taget ser spritkørerne i deres rekruttering ud til at placere sig imellem et typisk straffelovsklientel og normalbefolkningen, medens gerningspersonerne til gadevold er koncentreret til den mest belastede del af straffelovsovertræderne.

Skulle man sætte det lidt på spidsen, kunne man for det fjerde fristes til at påstå, at gerningspersonerne til gadevold er de - relativt fattige - der går hjem efter en lang aften på værtshus(e), medens spritbilisterne er de - relativt velbeslåede - der har en bil at køre i og som kører hjem. Alkohol er naturligvis en væsentlig bestanddel af spritkørslen, men den er det også af gadevolden. Hovedparten af gerningspersonerne til gadevold er berusede. Det er desuden korrekt, at gerningspersonerne til spritkørsel gennemgående er mere velstående og oftere har bil end gerningspersonerne til gadevold. Det har endvidere også vist sig, at størsteparten af spritkørere umiddelbart forinden har drukket på restaurant eller værtshus (Nielsen, 1978). Om vold med skade tilfølge ved vi, at den er stærkt koncentreret til områder med mange værtshuse og restauranter (Balvig m.fl., 1986). Dertil kommer i øvrigt, at en betydelig del af volden - mellem en fjerdedel og en tredjedel af den vold, der har medført skade - finder sted på værtshus eller i umiddelbar nærhed af værtshuse (Nielsen m.fl., 1984).

For det femte er både gadevold og spritkørsel lovovertrædelser med meget betydelige mørketal. Man regner med, at højest nogle få procent - måske kun brøkdele af en procent - af alle tilfælde af spritkørsel bliver opdaget og registreret. Hvis vi under gadevold også medtager chikanering, mobning o.lign. i gademiljøet, så bliver det også her højest nogle få procent, der kommer for dagens lys. På den anden side er mørketallene relativt beskedne ved de gadevoldstilfælde og sprituheld, hvor der forekommer mere alvorlig skadevoldelse. Mørketallene er først og fremmest store, hvor der ingen fysisk skade sker på nogen. Hvor der ingen fysisk skade er sket, kan man formode, at selve kontroltætheden - eksempelvis politirazziaer og almindelig politipatruljering - spiller en afgørende rolle for, hvor mange tilfælde der registreres og pådømmes. 
Teori

Som fælles hypoteser for de mest diskuterede risici i gademiljøet vokser da tre grundantagelser frem.

Det er for det første antagelsen om, at alkoholfaktoren spiller en vigtig rolle for problemernes absolutte størrelse.

Det er for det andet antagelsen om, at kontrolfaktoren er afgørende for, hvor stor en andel af problemerne, der bliver kendt (lysfeltet).

Og det er for det tredje en antagelse om, at den teknologiske udvikling og rigdom - bilbesiddelsen og transportmuligheder i det hele taget - spiller en vigtig rolle for, hvordan forholdet er mellem gadevold og spritkørsel: jo større bilbrug og bilbesiddelse, jo relativt flere tilfælde af spritkørsel i forhold til gadevold.

Af disse hypoteser følger en fjerde, nemlig at det kendte eller registrerede antal tilfælde ikke nødvendigvis varierer - geografisk eller tidsmæssigt - på samme måde som det faktiske antal, fordi deres årsager - alkoholfaktoren og kontrolfaktoren ikke nødvendigvis gør det. Konkret betyder dette, at tilfælde uden skader og tilfælde med skader ikke nødvendigvis er relaterede.

Endelig kan man så tilføje en femte hypotese af mere pragmatisk tilsnit, der påpeger den præventionseffekt, der kan ligge i kontrolfaktoren: jo større overvågning og kontrol, jo færre tilfælde af gadekriminalitet.

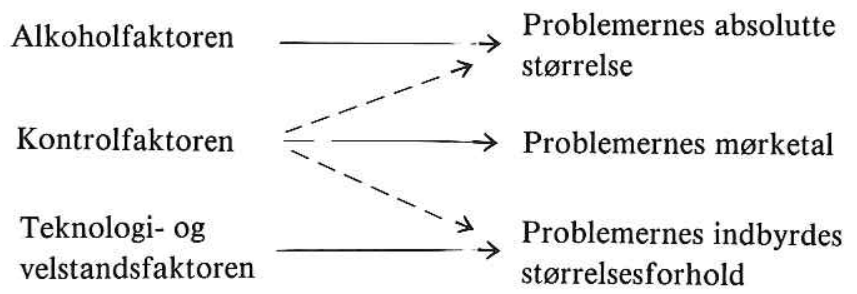

Når kontrolfaktoren i denne opstilling antages at påvirke problemernes faktiske indbyrdes størrelsesforhold er det ud fra den betragtning, at den næppe i sine mulige forebyggende virkninger har lige stor effekt på alle former for gadekriminalitet. Det beror bl.a. på de enkelte kriminalitetsformers grad af rationalitet.

At afprøve disse grundlæggende hypoteser og at indplacere dem i en bredere teoretisk og empirisk referenceramme, hvor man også bestemmer de forhold, der påvirker alkoholfaktoren, kontrolfaktoren m.v., er en umådelig omfattende opgave.

\section{Metodevalg}

Brug af alkohol og virkningerne af alkohol er stærkt kulturelt betinget. Det gør det problematisk at overføre resultater fra en kultur til en anden. Derfor må afprøvning af ovennævnte model ske fra land til land og fra tidsperiode til tidsperiode. Det er sandsynligt - og $\mathrm{i}$ et vist omfang allerede påvist - at sammenhængene vil tage sig for- 
skelligt ud fra land til land og fra tidsperiode til tidsperiode (se f. eks. Votey, 1978). At resultaterne kan forventes at være tidsspecifikke rejser særlige vanskeligheder, for jo kortere tidsperiode vi vælger at studere, jo færre observationer får vi til rådighed. Studier over tidsmæssige variationer gør det også ofte vanskeligt at holde relevante faktorer konstante. Det er derfor mere hensigtsmæssigt enten at studere forskelle mellem enkeltpersoner (ved interviewundersøgelser, vejkantsundersøgelser m.v.) eller - oftest langt lettere og billigere - mellem geografiske områder.

Dette taler da for, at hvis vi ønsker at vurdere de enkelte hypotesers og den samlede models relevans for Danmark her og nu - på en relativt billig og overkommelig måde - så er det nødvendigt med empiriske undersøgelser - og disse empiriske undersøgelser skal vedrøre danske forhold, vi skal studee nutidige forhold og vi skal få dynamikken og de nødvendige forskelle ind $\mathrm{i}$ undersøgelsen ved at koncentrere os om geografiske variationer.

De almindelige og tilgængelige kriminalstatistiske oplysninger gør det ikke umiddelbart muligt at foretage en sådan analyse med hensyn til gadevold. Derimod foreligger der relevante oplysninger om spritkørsel. Det er jo også, som vi har set, denne der forvolder de mest alvorlige fysiske skader.

\section{Analyse}

Den nugældende danske lovgivning vedrørende spritkørsel er fra 1976. I $1981 \mathrm{blev}$ der foretaget en vis liberalisering i form af en udvidelse af bødeområdet. For at få en nyere periode med et ensartet lovgrundlag er perioden 1982-85 blevet afgrænset som analyseperiode.

Danmark er opdelt i 54 politikredse. I selve analysen er udeladt den ene, Københavns politikreds, fordi det her ikke er muligt at danne et meningsfuldt og med de andre sammenligneligt mål for kontrolfaktoren. Der indgår således 53 politikredse i undersøgelsen.

Det er fremgået, at meget af den spiritusindtagelse, der går forud for spritkørsel, synes at finde sted på værtshuse og restauranter. Et af de mulige relevante mål for alkoholfaktoren er således antal værtshuse og restauranter, og for hvert af områderne er udregnet antal værtshuse m.v. med alkoholbevillinger i forhold til folketallet. forhold til folketallet.

Det er ordenspolitiet, der inden for det formelle kontrolapparat har overvågning og bekæmpelse af spritkørslen som sit arbejdsområde. Et af de mulige relevante mål for kontrolfaktoren er derfor antallet af ordensbetjente i forhold til folketallet, og også dette er udregnet $\mathrm{i}$ forhold til folketallet for de enkelte politikredse. I kredse med grænseovergange er paspolitiet fratrukket.

Kun et mindretal af de tilfælde af spritkørsel, der ikke resulterer i uheld, kommer til politiets kundskab gennem anmeldelse. En undersøgelse i Århus politikreds af perioden 1972-77 viste, at kun $28 \%$ af sagerne vedrørende spritkørsel uden uheld hav- 
de deres baggrund i et ikke-politimæssigt initiativ (Koch, 1979). Det synes følgelig relevant at vurdere spritsager uden uheld som primær funktion af kontroltæthed og derved som et mål for spritkørselsproblemets lysfelt. (Langt den største del af de registrerede tilfælde af spritkørsel er sager, hvor der ikke er sket uheld. Analyseresultater med hensyn til denne størrelse kan derfor betragtes som - og er - identiske med analyseresultater for det samlede antal sigtelser for spritkørsel).

Omvendt viste samme undersøgelse i Århus, at langt de fleste spritsager med uheld - $92 \%$ - havde deres baggrund $i$ en anmeldelse og ikke $i$ et politimæssigt initiativ. Især vil der være grund til at tro, at variationer i spritkørselssager med personskader er en rimelig reel indikator på variationer i det faktiske antal spritkørsler, specielt hvis disse variationer er betydelige.

Spritkørsel med uheld men uden personskade må formodes at indtage en slags mellemstilling mellem spritkørsel uden uheld og spritkørsel med personskade, dvs. at variationer i denne størrelse både kan antages påvirket af mørketalsforskydninger via kontrolfaktoren og reelle ændringer via alkohol- og færdselsintensitetsfaktoren. (Resultaterne af undersøgelsen med hensyn til denne faktor gengives ikke i denne artikel. Analysen viser, at spritkørsel med uheld uden personskade indtager nævnte mellemstilling, altså at antagelsen af korrekt).

Med disse oversættelser eller operationaliseringer af modellens hovedvariable og under forudsætning af uafhængighed mellem ordenspolititæthed og antal alkoholbevillinger - får den empiriske model følgende udseende, idet det er underforstået at alle variable er vurderet i forhold til folketallets størrelse:

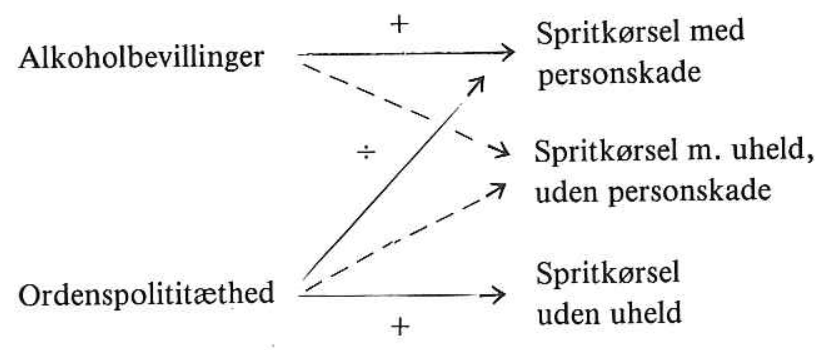

En udregning af korrelationskoefficienterne for relationen mellem alkoholbevillinger og ordenspolititæthed bekræfter, at disse to størrelser varierer uafhængigt af hinanden. Korrelationerne havde følgende størrelsesorden

Alkoholbevillinger og ordenspolititæthed

$\begin{array}{ll}\text { 1982: } & -.0578 \\ \text { 1983: } & -.0616 \\ \text { 1984: } & -.1216 \\ \text { 1985: } & -.1266\end{array}$ 
Koefficienterne er langt fra statistisk signifikans. Det samme gælder, hvis man ser på ændringerne fra år til år:

1982-83: $\quad .1658$

1983-84: $\quad .2190$

1984-85: $\quad-.1500$

Udregning af korrelationskoefficienterne bekræfter også, at sigtelser for spritkørsel med personskade og spritkørsel uden uheld synes at være to uafhængige størrelser, hvorfor de må være indikatorer på forskellige forhold og have hver sin specifikke forklaring:

Spritkørsel med personskade og spritkørsel uden uheld

$\begin{array}{rr}\text { 1982: } & .0895 \\ \text { 1983: } & -.1795 \\ 1984: & -.2308 \\ \text { 1985: } & -.0375 \\ \text { 1982-83: } & -.0405 \\ \text { 1983-84: } & -.1041 \\ 1984-85: & .2710\end{array}$

Hverken de geografiske variationer i de enkelte år eller de tidsmæssige forandringer fra år til år i de enkelte områder udviser en eneste statistisk signifikant variation.

For hele perioden er der i det samlede antal sigtelser for spritkørsel en kraftig overvægt af spritkørsel uden uheld. Det følger heraf - og af de forudgående ræsonnementer - at variationer i det samlede antal må forventes snarere at afspejle variationer i mørketallets størrelse end reelle variationer.

Det er vigtigt ved en afprøvning af en model som den opstillede at vurdere om eventuelle sammenhænge er falske eller betingede. Derfor er der ud over de centrale variable indhentet oplysninger om følgende yderligere variable for de 53 politikredse som kunne antages måske at påvirke gadekriminalitet, her spritkørsel, i et område:

\section{Omfanget af kulturvariation}

Andel udlændinge

Andel udlændinge fra lande i EF eller Norden

Andel udlændinge fra lande uden for EF og Norden

Omfanget af anomi

Social turbulens (hyppighed af flytninger)

Selvmordshyppighed

Selvmordshyppighed for mænd

Selvmordshyppighed for kvinder

Omfanget af uformel social kontrol

Områdets grad af bymæssighed

Andel 15-19-årige indskrevet i klubber

Andel 15-24-årige af den samlede befolkning 


\section{Socioøkonomiske forhold}

Andel ufaglærte arbejdere blandt lønmodtagere

Gennemsnitsløn for ufaglærte arbejdere

Lønforskel mellem ufaglærte arbejdere og funktionærer (målestok for ulighed/ relativ deprivation)

Udbetalt kontanthjælp pr. indb. (målestok for økonomiske problemer)

Total arbejdsløshedsprocent

Ungdomsarbejdsløshedsprocent

Andel lejligheder i flerfamiliehuse af den samlede boligmasse

Antal biler pr. indbygger

Øvrige aspekter ved den formelle kontrol

Andel ordensbetjente af samlet politistyrke

Antal politihunde pr. ordensbetjent

Andel af ordenspolitistyrke $<$ lønramme 15

Antal kriminalbetjente i forhold til indbyggertallet

I analyserne er disse variable systematisk anvendt som kontrolvariable i de multiple regressionsanalyser, variansanalyser og betingede korrelationsanalyser der er brugt ved analysen af den empiriske models hovedantagelser. Oplysninger om kontrolvariable foreligger kun fuldstændigt for årene 1982 og 1983 og kan således kun i begrænset omfang anvendes ved analysen af tidsmæssige ændringer.

\section{Polititcethed og spritkørslens mørketal}

En udregning af korrelationskoefficienterne for forholdet mellem antal ordensbetjente pr. 10.000 indbyggere og sigtelser for spritkørsel uden uheld for de 53 politikredse giver følgende resultat:

Ordenspolititæthed og spritkørsel uden uheld

1982: $.4574^{* *}$ 1983: $.5504^{* *}$ 1984: $.5111^{* *}$ 1985: .6071**

En markering med to stjerner - ** - betyder her som andre steder i fremstillingen stærk signifikans $(p<0.001)$, og en markering med en enkelt stjerne - * - signifikans ( $\mathrm{p}<0.01)$. Koefficienternes størrelse, der alle er stærkt statistisk signifikante, bestyrker antagelsen om en tæt sammenhæng mellem kontrolfaktoren og mørketallet størrelse.

En multipel regressionsanalyse for årene 1982 og 1983, hvori indgår samtlige de tidligere nævnte kontrolvariable samt den anden centrale variabel i modellen - antal alkoholbevillinger - viser videre, at ordenspolititætheden er den eneste, der udviser statistisk signifikant variation med antallet af sigtelser for spritkørsel uden uheld. Når ordenspolititætheden holdes konstant, forsvinder de eventuelle samvariationer mellem andre faktorer og registrerede tilfælde af spritkørsel uden uheld. Følgende 
opstilling viser manglen på statistisk signifikant sammenhæng med alkoholbevillinger:

Alkoholbevillinger og spritkørsel uden uheld

$$
\begin{array}{ll}
\text { 1982: } & -.0971 \\
\text { 1983: } & -.2124 \\
\text { 1984: } & .0407 \\
\text { 1985: } & .0005
\end{array}
$$

Regressionsligningen for forholdet mellem ordenspolititæthed og spritkørsel uden uheld for de fire år adskiller sig ikke væsentligt fra hinanden. For 1985 ser ligningen således ud:

$(\mathrm{SUUH})=1.6152(\mathrm{PT})+9.3275(\mathrm{~F}=29.7724, \mathrm{p}<0.001)$

hvor (SUUH) er antal sigtelser for spritkørsel uden uheld pr. 10.000 indbyggere og (PT) antal normerede ordensbetjente, eksklusiv evt. paspoliti, pr. 10.000 indbyggere - dvs. at en ordensbetjent mere pr. 10.000 indbyggere i gennemsnit betyder i størrelsesordenen 1 ekstra spritsag uden uheld pr. 6250 indbyggere.

Løgstør politikreds havde den mindste ordenspolititæthed. I overensstemmelse hermed havde man også landets mindste hyppighed af sigtede for spritkørsel uden uheld, omkring 1 pr. 1000 indbyggere. Den højeste ordenspolititæthed havde Gentofte politikreds. Man havde ikke her det største antal spritkørsler uden uheld, men dog det tredjestørste i landet, omkring 1 pr. 300 indbyggere. Det højeste antal havde Gråsten politikreds.

En sandsynliggørelse af politiaktivitetens dominerende indflydelse på omfanget af sigtelser for spritkørsel uden uheld får man ved at sammenholde ordenspolitiets »indflydelse« med kriminalpolitiets. Som man måtte vente, hvis sammenhængen skal være meningsfuld, viser det sig for det første, at ordenspolititætheden umiddelbart har den stærkeste sammenhæng og kriminalpolititætheden den svageste med registrerede tilfælde af spritkørsel uden uheld i alle årene. For det andet viser det sig, at holder man ordenspolititætheden konstant, så forsvinder sammenhængen helt med kriminalpolititætheden. Det er ordenspolititætheden, der spiller en rolle. Kriminalpolititætheden spiller i denne sammenhæng ingen rolle.

Man kunne forvente, at hvis det havde været muligt at få nogle endnu mere konkrete og direkte mål for ordenspolitiets indsats, såsom omfanget af patruljering og antallet af razziaer, så ville vi have kunnet registrere en endnu stærkere sammenhæng med antal spritkørsler uden uheld end vi finder for de totale normeringstal. En grov indikator for politipatruljeringens omfang findes i oplysninger om, hvor mange udrykninger, der er sket fra kørende patrulje og hvor mange, der er sket fra politistationer. Hverken andelen af udrykninger, der er sket fra en kørende patrulje, antallet af disse udrykninger pr. betjent eller pr. indbygger udviser imidlertid stærkere sammenhæng med spritkørsler end antallet af ordensbetjente. Det kunne derfor tyde på, at det er selve antallet af betjente og de ressourcer som antallet gør muligt at sætte ind på patruljering m.v., der er afgørende. 
Hvis vi betragter den tidsmcessige udvikling fra 1982 til 1985 ser det ikke umiddelbart ud som om kontrolfaktoren kan forklare eller beskrive dette forløb. Af nedenstående opstilling kan man se, hvordan udviklingen i sigtelser for spritkørsel uden uheld i forhold til folketallet har udviklet sig sammenholdt med, hvad vi skulle vente hvis ovenstående regressionligning baseret på de geografiske variationer i 1985 havde »styret« forløbet. Opstillingens tal er indekstal, hvor tallene for 1982 er sat lig med 100:

Sigtelser for spritkørsel uden uheld i forhold til folketallet

$\begin{array}{ccc}\AA \text { År } & \text { Faktisk antal } & \text { Beregnet antal } \\ 1982 & 100 & 100 \\ 1983 & 92 & 102 \\ 1984 & 86 & 105 \\ 1985 & 79 & 109\end{array}$

I perioden er der sket en forøgelse af ordenspolitistyrken i Danmark og ud fra den skulle man som vist have forventet en klar og konsekvent stigning i sigtelsernes antal. Den faktiske udvikling er imidlertid stik modsat. Sigtelserne for spritkørsel uden uheld er faldet konsekvent og betragteligt. I 1985 ligger niveauet mere end en fjerdedel under det niveau, man skulle have forventet ud fra modellen.

Også hvis vi ser på korrelationskoefficienterne for de tidsmæssige ændringer i ordenspolitimænd og spritkørsler uden uheld i forskellige områder får vi et resultat, der ikke harmonerer med kontrolhypotesen:

$$
\begin{array}{ll}
\text { 1982-83: } & -.0119 \\
\text { 1983-84: } & .0411 \\
\text { 1984-85: } & .1050
\end{array}
$$

Ingen af koefficienterne er statistisk signifikante. En af de mulige forklaringer herpå er, at det tager et stykke tid inden en ændring vil slå igennem. En forøgelse af ordenspolitistyrken kan jo f. eks. også i et område være sket sidst på året, og må da forventes først at slå rigtigt igennem $i$ det følgende år. Man kan derfor prøve at se på korrelationerne for tidsforskudte sammenhænge, f. eks. ændringen i ordenspolititætheden for 1982-83 sammenholdt med ændringen i spritkørsel uden uheld 1983-84 osv. Faktisk går alle disse korrelationskoefficienter i den forventede retning, dvs. de er positive og de er større end de ovenfor næunte. Men ikke en eneste af dem er statistisk signifikant.

Hovedforklaringen er da nok også en anden, nemlig at vi prøver at aflæse effekten af noget, der har forandret sig meget lidt. Forskydningerne i ordenspolititætheden er små, ikke mindst i sammenligning med de geografiske variationer inden for et år. F. eks. er det gennemsnitlige antal ordensbetjente pr. 10.000 indbyggere for de 53 politikredse i 1985 9. Den mindst bemandede kreds havde 4, den højest bemandede 14 , dvs. en spændvidde på 10. I kontrast hertil er den gennemsnitlige forskel i ordensbetjenttætheden fra 1984 til 1985 under 1, den mindste ændring er 0 og den stør- 
ste 2. Totalt er spændvidden altså her kun 2. Med så små variationer må man regne med, at tilfældigheder kommer til at spille en afgørende rolle og at ændringer i relevante konkrete tiltag såsom omfanget af patruljering ikke nødvendigvis følger ændringer i ordenspolititætheden. I tråd med denne fortolkning skulle man jo dog vente, at de største ændringer i ordenspolititætheden skulle udvide registrerbare udslag på registrerede spritkørsler uden uheld. Dette er også tilfældet, hvilket kan illustreres ved udviklingen fra 1984-85:

$\begin{array}{cc}\begin{array}{c}\text { Gns. forskel i } \\ \text { ordenspoliti- } \\ \text { tætheden }\end{array} & \text { spritkørsel } \\ \text { uden uheld }\end{array}$

De 6 politikredse, hvor ordenspolititætheden er steget mindst.

$\begin{array}{ll}0.0 & -2.7 \\ 0.6 & -1.7\end{array}$

Gns. for alle politikredse

De 6 politikredse, hvor ordenspolititætheden er steget mest.

$\begin{array}{ll}1.7 & 0.3\end{array}$

I 5 af de 6 politikredse, hvor ordenspolititætheden er steget mindst - eller faldet - er der også sket et fald i antal spritkørsler uden uheld. Omvendt er der i fire af de seks politikredse, hvor ordenspolititætheden er steget mest, også sket en stigning. Dette taler således for, at kontrolfaktoren er virksomhed over tid, men at kontrollen gennemgående varierer så lidt inden for det tidsmæssige perspektiv, vi har anvendt, at disse ændringer ikke har haft styrke til at slå igennem.

Under alle omstændigheder er det jo dog overraskende - og uden for det forventede - at der er sket et så betydeligt fald i antallet af sigtede for spritkørsel uden uheld fra 1982 til 1985. En af de mulige og nærliggende forklaringer er, at man trods uændret eller forhøjet normering reelt p.g.a. ferieudvidelse, sygdom el. lign. gennemgående har haft mindre tid til rådighed og/eller at man i faldende grad har benyttet den til rådighed værende tid på initiativer i forbindelse med spritkørsel, bl.a. måske fordi man i stigende grad har overtaget arbejdsopgaver fra kriminalpolitiet netop i denne periode. Det er en forklaringsmulighed af samme art, men med omvendt fortegn, som den - plausible - forklaring, der er givet på en stærk stigning i tallene for spritkørsler uden uheld - til trods for stort set uændret generel polititæthed - efter vedtagelsen af den nye færdselslov i 1976 (Koch, 1979). Lovgivningsændringen i 1976 gjorde det lettere, hurtigere og mere motiverende for ordenspolitiet at initiere kontrol på spritkørselsområdet end tidligere. Lignende spring opad i den registrerede spritkørsels omfang er set i mange andre lande efter gennemførsel af en tilsvarende lovgivning, eksempelvis i Californien i 1966 (Bunce m.fl., 1981) og i Holland i 1976 (Begeer, 1986). 


\section{Alkoholbevillinger og spritkørsel}

Som udgangspunkt for vurdering af hypotesen om antallet af værtshuses og restauranters direkte betydning for den faktiske spritkørsels omfang, kan vi igen foretage en udregning af de simple korrelationskoefficienter:

Alkoholbevillinger og spritkørsel $\mathrm{m}$. personskade

1982: $.3768^{*}$

1983: $.4366^{*}$

1984: $.3480^{*}$

1985: .3212*

For alle fire år er der en positiv og statistisk signifikant sammenhæng mellem antal alkoholbevillinger pr. 10.000 indbyggere og antal sigtelser for spritkørsel med personskade, ligeledes pr. 10.000 indbyggere. Antagelsen bestyrkes således, selv om korrelationerne ikke når samme niveau som for kontrolhypotesens vedkommende.

Hypotesen bestyrkes videre af gennemførte udregninger af partielle korrelationskoefficienter, gennemførte variansanalyser og multiple regressionsanalyser, hvori alle kontrolvariable er inddraget (eksklusiv polititæthed, som vi skal vende tilbage til). Antallet af alkoholbevillinger er den eneste faktor, der udviser systematisk statistisk signifikant sammenhæng med sigtelser for spritkørsel med personskade.Når alkoholfaktoren holdes konstant, forsvinder eventuelle samvariationer mellem andre faktorer og registrerede tilfælde af spritkørsel.

Der ligger en sandsynliggørelse af omfanget af udskænkningssteders reelle indflydelse på spritkørslens variationer i yderligere to forhold. For det første spiller alkoholbevillingernes antal også en - om end mere beskeden - rolle for den øvrige kriminalitet, herunder især voldskriminaliteten. For det andet udviser sigtelser for spritkørsel med personskade en vis sammenhæng med den øvrige kriminalitet. Det gør sigtelser for spritkørsel uden uheld ikke. Spritkørsel med personskade synes derfor wintegreret« på en måde i det øvrige kriminalitetsbillede, der svarer til, hvad man skulle forvente ud fra antagelsen om antal sigtede i disse sager som reel kriminalitetsindikator.

Et vigtigt og interessant spørgsmål er, hvorvidt det er en specifik og konkret alkoholfaktor, der påvirker spritkørslen, eller om alkoholfaktoren blot er en indikator for et bredere årsagsforhold. Man kunne f. eks. forestille sig, at antallet af alkoholbevillinger $i$ et område fungerer som en slags livsstilsindikator, hvor mange værtshuse indicerer en mere kortsigtet, ureflekteret og grænseprøvende livsstil og få en mere langsigtet, nøgtern og generel konform levevis. En sådan fortolkning passer godt ind i den konstaterede sammenhæng mellem spritkørsel og anden kriminalitet.

Hvis omfanget af alkoholbevillinger er en livsstilindikator af nævnte art skulle man forvente, at den ville være korreleret med trafikulykker, hvor der ikke indgår spiritus, men som er forvoldt af »almindelig« uagtsom kørsel. Korrelationskoefficienterne for forholdet mellem antal alkoholbevillinger i et område og hyppigheden af trafikulykker med personskade, hvor føreren af transportmidlet ikke har været spirituspåvirket, har følgende størrelse: 
Alkoholbevillinger og uheld m. personskade (ekskl. spritkørsel)

1982: .2508

1983: .4474**

1984: .3826*

1985: .3966*

For tre af årene er der en signifikant sammenhæng og generelt adskiller koefficienternes størrelsesorden sig ikke fra dem, vi har fundet for sammenhængen mellem alkoholbevillinger og spritkørsel. Det tyder da på, at der i højere grad er tale om en bredere livsstilkomponent end en isoleret og specifik alkoholfaktor. Herved modbevises selvfølgelig ikke, at indtagelse af alkohol kan være en direkte årsag til en trafikulykke (se f. eks. Greve, 1979, for en oversigt over litteratur herom), men det er en advarsel mod isoleret at vurdere spritkørselproblemet som et rent kemisk og mekanisk spørgsmål om spiritusindtagelse i forbindelse med transport. Man må bl.a. huske på, at en dom for spritkørsel (med eller uden personskade) ikke i den nugældende danske lovgivning (om denne se f. eks. Waage, 1985) er ensbetydende med, at det er påvist, at det er spritten, der har forårsaget uheldet. Det er alene en konstatering af, at føreren har mere end et vist kvantum sprit i blodet. Man må ud fra analyserne her formode, at et betragteligt antal af de forekomne sprituheld (med eller uden personskade), ville være sket alligevel, selv om føreren »tilfældigvis« havde indtaget mindre eller slet ingen spiritus.

En retsmediciner har forklaret spritbilisters forhøjede ulykkesrisiko på bl.a. følgende måde: "Alkohol er farlig i trafikken, først og fremmest fordi de påvirkedes hæmninger nedsættes, de får en urealistisk tro på egne evner, bliver tilbøjelige til at tage chancer, reagerer pludseligt og overdrevent, kører for hurtigt, lader hånt om færdselsreglerne« (Dalgaard, 1978). Den her beskrevne situation og de beskrevne køreegenskaber kan udspringe af andet end alkohol. Det er i vid udstrækning en rollebeskrivelse, og man genkender flere træk fra andre beskrivelser af især den traditionelle senpubertetsmæssige mandsrolle. Man kunne med god ret erstatte »alkohol« i beskrivelsen med »den senpubertetsmæssige traditionelle mandsrolle«.

Såvel på det individuelle som på det geografiske niveau er der sikkert tale om et tæt samspil mellem generelle livsstilsmønstre og det specifikke udslag af en livsstil, som alkoholindtagelse er. På det geografiske niveau må man antage, at en mere kortsigtet, udfoldende livsstil i et område øger efterspørgslen på værtshuse og restauranter, som derfor vil have en tendens til at tiltage $i$ antal og blive en »indikator" for denne livsstil - men at et øget udbud af værtshuse og restauranter i et område også på sin side kan øge efterspørgslen og dermed selvstændigt præge omfanget og karakteren af en bestemt livsstil.

Regressionsligningen for forholdet mellem alkoholbevillinger og spritkørsel med personskade adskiller sig ikke væsentligt fra hinanden for de fire år. For 1985 ser ligningen således ud:

$(\mathrm{SMP})=0.08802(\mathrm{AB})+2.4632(\mathrm{~F}=5.8651, \mathrm{p}<0.01)$ 
hvor (SMP) er antal sigtelser for spritkørsel med personskade pr. 10.000 indbyggere og (AB) antal alkoholbevillinger pr. 10.000 indbyggere - dvs. at 1 værtshus mere pr. 10.000 indbyggere betyder i størrelsesordenen 1 ekstra spritsag med personskade pr. 110.000 indbyggere. Blandt de politikredse, der ligger lavt med hensyn til såvel antal værtshuse som sigtelser for spritkørsel med personskade er en del af de københavnske forstadspolitikredse såsom Hvidovre, Glostrup, Gladsaxe og Tårnby. Den geografiske placering af de politikredse, der ligger højest i begge henseender, er mere diffust, men har måske et fælles udgangspunkt $i$, at det gennemgående er ferieområder og/eller områder med spritruter/grænseovergange såsom Bornholm, Grenå, Gråsten, Svendborg og Nykøbing F. politikredse.

Af nedenstående opstilling kan man i indeksform se, hvordan udviklingen i sigtelser for spritkørsler med personskade i forhold til folketallet har været fra 1982 til 1985 sammenholdt med, hvordan man ud fra regressionsligningen skulle have forventet den:

Sigtelser for spritkørsel med personskade i forhold til folketallet:

$\begin{array}{ccc}\AA ̊ & \text { Faktisk antal } & \text { Beregnet antal } \\ 1982 & 100 & 100 \\ 1983 & 96 & 101 \\ 1984 & 90 & 102 \\ 1985 & 87 & 103\end{array}$

Hvor man skulle have ventet en lille stiging, fordi antallet af værtshuse og restauranter er steget, er der faktisk sket et fald. Der er i 1985 15\% færre tilfælde af spritkørsel med uheld end man skulle have forventet.

Korrelationskoefficienterne for de tidsmæssige ændringer i forskellige områder harmonerer heller ikke umiddelbart med tesen om alkoholbevillingernes indflydelse på variationer i faktisk spritkørsel:

$\begin{array}{ll}\text { 1982-83: } & -.1011 \\ \text { 1983-84: } & .0050 \\ 1984-85: & .1996\end{array}$

Uoverensstemmelsen mellem den geografiske og den tidsmæssige model kan som ved analysen af kontrolfaktoren også her forklares ved, at variationerne i den forklarende faktokr - alkoholbevillingerne - er relativt små, og at man rimeligvis må regne med en vis tidsforskydning. Dels kan man for det enkelte år iagttage, at de største forandringer giver den forventede effekt: Fra 1984 til 1985 er Køge eksempelvis den politikreds, der har haft den største reduktion i antal værthuse og restauranter, og det er samtidig den kreds, hvor sigtelser for spritkørsel med personskade er faldet mest. Vordingborg er den politikreds, hvor alkoholbevillingernes antal er steget mest - og det sted, hvor også sigtelser for spritkørsel er steget stærkest. Dels kan man konstatere, at korrelationskoefficienterne tiltager i størrelse, når ændringer be- 
tragtes over en længere periode, og når der tages højde for eventuelle tidsforskydninger af effekten. Den mulighed, der findes i materialet for at studere ændringer over en to-årsperiode og med en et-årig tidsforskydning, giver en signifikant korrelation af en størrelsesorden der svarer til den geografiske model (.3498*). Regressionsligningen er følgende:

$(\mathrm{SMPU})=0.1221(\mathrm{ABU})-0.5269(\mathrm{~F}=7.11144, \mathrm{p}<0.01)$

(SMPU) er forskellen i antal sigtelser for spritkørsel med personskade pr. 10.000 indbyggere og (ABU) antal alkoholbevillinger pr. 10.000 indbyggere. Det antal alkoholbevillinger, der skal til i denne ligning for at forøge spritkørslerne med et givet antal, er ikke signifikant forskellig fra det, vi fandt for den geografiske model.

Derimod kan man se, at ligningens skæringspunkt med ordinataksen her er negativ (-0.5259), hvilket jo blot er et »matematisk « udtryk for, at spritkørslernes antal gennemgående er faldet $\mathrm{i}$ de områder, hvor antallet af værtshuse m.v. har været uforandret. Det er en konkret illustration af den almene faldgrube, der eksisterer, når man alene betragter bruttoforandringer. Umiddelbart kunne man jo være tilbøjelig til at afvise, at alkoholbevillinger kan have nogen indflydelse på spritkørsler, når udviklingen totalt eller brutto er gået i retning af flere værtshuse m.v., men færre spritkørsler. En udvikling vil næsten altid være en nettoudvikling, dvs. et produkt af faktorer, der har presset hver sin vej, men man har en tilbøjelighed til at overse de faktorer, der har presset i modsat retning af totaludviklingen. For situationen her med sammenhængen mellem alkoholbevillinger og værtshuse kan man illustrere det på den måde, at hvis antallet af alkoholbevillinger fra 1982 til 1985 havde holdt sig konstant, så havde faldet i sigtelser for spritkørsel med personskade været på omkring $20 \%$ og ikke på de nævnte $13 \%$.

Det bestyrker antagelsen om alkoholfaktorens betydning, at den bekræftes af analysen af de tidsmæssige variationer, men det er vigtigt at være opmærksom på det ofte oversete forhold, at en sådan overensstemmelse ikke er en nødvendig betingelse for hypotesens holdbarhed. Variationer omkring et bestemt niveau behøver ikke nødvendigvis have de samme forklaringer som variationer over tid. Den store forskel i kriminalitet mellem Vestjylland og København skyldes måske primært forskelle $\mathrm{i}$ urbaniseringsgrad, men det kan være helt andre forhold, der forklarer at stigningen fra det ene til det andet år er forskellig. Disse forskelle kan eksempelvis skyldes forskelle i arbejdsløsheden. Specielt er der grund til at være opmærksom på muligheden for, at variationer i et forhold forklares ved en »flødeskumsteori«: Den store brede substans i »lagkagen « har sin årsag i bestemte forhold, medens det mere flygtige flødeskum ovenpå let kan blæses af eller fyldes på - en proces der har andre årsager. Hvis denne situation er fremherskende, får man én teori frem, hvis man studerer »flødeskummet« (udviklingen) og en anden hvis man studerer »lagkagen« (nieauet). Ud fra en kriminalpræventiv synsvinkel er det niveauet, der er det centrale at nedbringe, fordi det udgør den største del af den samlede »kage«. 


\section{Polititcethed og spritkørsel}

Det er da en mulighed, at det fald, der har været i antal sigtede for spritkørsel med personskade, kan have sin baggrund i en sådan »flødeskumsfaktor «, som vi ikke har kunnet opfange i de geografiske analyser. En anden mulighed er, at den tredje hovedantagelse i vor udgangsmodel - om de præventive virkninger af politikontrol forklarer faldet.

Vi kan først se, om der i de geografiske variationer er nogen støtte at hente for denne hypotese:

Ordenspolititæthed og spritkørsel med personskade

$$
\begin{array}{ll}
\text { 1982: } & -.2044 \\
\text { 1983: } & -.2892 \\
\text { 1984: } & -.3833^{*} \\
\text { 1985: } & -.2132
\end{array}
$$

Korrelationskoefficienterne mellem ordenspolititæthed og antal spritkørsler med personskade går alle i den forventede retning - jo mere ordenspoliti, jo mindre spritkørsel, men kun en enkelt er statistisk signifikant.

Den afskrækkende virkning må antages helt at bero på den risiko for opdagelse, som det psykologisk lykkes politiet $i$ et område at afsætte i de potentielle spritkøreres bevidsthed. Og dette må igen antages hovedsageligt at bero på, hvor ofte man ser og møder politiet, dvs. på omfanget af generel patruljering og specielle razziaer. Vi har beregnet korrelationskoefficienterne mellem den tidligere nævnte patruljeringsindikator (andel af samlet antal udrykninger, der ikke er foretaget med udgangspunkt i en politistation) og spritkørsel med personskade:

Patruljeringsniveau og spritkørsel med personskade

$$
\begin{aligned}
& \text { 1982: }-. .4481^{* *} \\
& \text { 1983: }-.4733^{* *} \\
& \text { 1984: }-.6724^{* *} \\
& \text { 1985: }-.5958^{* *}
\end{aligned}
$$

Korrelationskoefficienterne er stærkt statistisk signifikante for alle fire år. Holder man patruljeringsniveauet konstant forsvinder sammenhængen helt mellem ordenspolititæthed og spritkørsel med personskade. Der er en vis, men dog overraskende begrænset, sammenhæng mellem ordenspolitiets størrelse og patruljeringsniveauet. Man kan derfor konkludere, at politiets generelle påvirkningsformåen med hensyn til spritkørsel nok så meget er bestemt af, hvordan politiet kvalitativt tilrettelægger og prioriterer sit arbejde som rent kvantitative, ressourcemæssige forhold.

Et særligt forhold ved spritkørsel i forhold til anden afvigende trafikadfærd er, at »beslutningen« altid træffes inden kørslen evt. påbegyndes. Provokerende kørsel, hastighedsoverskridelser m.v. er sjældnere besluttet inden kørslens påbegyndelse. Denne forskel må også have betydning med hensyn til, hvad der hæmmer eller fremmer en bestemt afvigende trafikadfærd. Man kunne således vente, at spritkørslen ville være mere påvirkelig af en almen oplevelse af, hvor meget politi der findes og patruljerer $\mathrm{i}$ et område baseret på tidligere erfaringer, medens provokerende kørsel 
m.v. i højere grad er bestemt af om man lige har set eller ser politi i den konkrete kørselssituation. Med andre ord er det tvivlsomt, om vi også på andre trafikkriminalitetsområder vil finde en tilsvarende afskrækkende virkning af det generelle patruljeringsniveau som ved spritkørsel. Nedenstående opstilling viser da også, at der ikke er nogen sammenhæng mellem det almene patruljeringsniveau på den ene side og forekomsten af trafikuheld med personskade, hvori der ikke indgår spritkørsel, på den anden:

Patruljeringsniveau og uheld m. personskade (ekskl. spritkørsel)

$$
\begin{array}{ll}
\text { 1982: } & .0308 \\
\text { 1983: } & -.0669 \\
\text { 1984: } & .0874 \\
\text { 1985: } & .0433
\end{array}
$$

Den præventive effekt synes altså at være specifik i forhold til spritkørslen. Det kan i den forbindelse nævnes, at polititæthed og patruljeringsniveau ikke udviser nogen sammenhæng med antal straffelovsovertrædelser under ét, og heller ikke med undergrupper som tyveri og vold.

Specielt $\mathrm{i}$ forhold til den mulige generalpræventive effekt af retlige indgreb har man hæftet sig ved muligheden af, at denne effekt ikke er lige stor for alle befolkningsgrupper. For spritkørslens vedkommende har man bl.a. fremført den formodning, at effekten er størst for de højeste sociale lag - hvor man har mest at miste, har det bedste økonomiske grundlag for at tage en taxa i stedet for osv. - og mindst for de laveste sociale lag. En sådan socialt selektiv virkning af opdagelses- og straftruslen kunne være en af forklaringerne på, at man blandt de registrerede spritkørere finder en overvægt af personer fra de lavere sociale lag (Andenæs, 1978). Umiddelbart finder vi imidlertid ikke i nærværende undersøgelse at sammenhængen mellem politipatruljering og spritkørsel er forskellig for forskellige typer af områder, f. eks. grupperet efter andel ufaglærte arbejdere eller andel af boligmassen, der består af villaer.

Derimod er der et samspil mellem de to hovedvariable, der påvirker spritkørslens omfang, værtshustæthed og patruljeringsniveau. Dette samspil har den karakter, at kun i områder med relativt få værtshuse kan man aflæse en forebyggende effekt af øget politipatruljering. I områder med relativt mange værtshuse er der ikke nogen statistisk signifikant sammenhæng mellem patruljeringsniveau og antal sprituheld med personskade. Én mulig fortolkning har tråde tilbage til den livsstilsindikator, som alkoholfaktoren synes at være. Hvis det er rigtigt, at en kortsigtet livsstil er mere fremherskende i områder med mange værtshuse, må man også forvente at »langsigtede « vurderinger inden kørslen påbegyndes af, om man risikerer at blive opdaget og taget af politiet, er mindre fremherskende her - hvorved patruljeringsfaktoren får mindre betydning. 
Set over tid må vi endnu en gang konstatere, at vi ikke finder tilsvarende sammenhænge som inden for de enkelte år - og at det igen hovedsagelig skyldes, at de tidsmæssige variationer er forholdsvis små. Det skyldes muligvis også, at den anvendte indikator på patruljeringsniveau mindre godt opfanger forskydninger i patruljeringen over tid end forskelle mellem områder inden for samme år. Betragter vi de største forskydninger, går tendenserne i den forventede retning. Vi må derfor sige, at den øgning, der synes at være sket i politipatruljeringen fra 1982 til 1985, er noget men ikke hele - forklaringen på det fald, der har været i spritkørslen. Størrelsesordenen af effekten synes nærmest at være den, at den øgede patruljering har forebygget ligeså mange tilfælde som det øgede antal værtshuse har skabt.

\section{Sammenfatning}

Der er i denne artikel blevet gengivet resultater fra en undersøgelse af antal sigtelser for spritkørsel i Danmark for perioden 1982-1985. Som det fremgår af figuren er det en periode, hvor dette antal har været faldende efter ellers at have været stærkt stigende i mange år. Der er undersøgt dels variationerne mellem 53 af landets 54 politikredse inden for de enkelte år og dels ændringerne fra år til år.

Undersøgelsen viser klart, at variationerne i det samlede antal sigtelser for spritkørsel - der for hovedpartens vedkommende er sager, hvor der ikke er sket egentlige uheld - først og fremmest er et udtryk for, hvor omfattende kontrol der sættes ind på dette område. Statistikken på dette område må derfor siges at være en statistik over kontrolbestræbelser og ikke over spritkørslens faktiske forekomst og variationer. Eksempelvis får man et helt misvisende billede for de københavnske forstæder. Disse områder ligger blandt de højeste med hensyn til antal registrerede tilfælde af spritkørsel - på grund af en særligt omfattende kontroltæthed - men blandt de laveste i den reelle forekomst af spritkørsel.

Det fald der er sket $i$ de senere år i det samlede antal sigtelser for spritkørsel beror formentlig primært på en noget sænket kontrolaktivitet på området, der bl.a. kan være foranlediget af, at ordenspolitiet $i$ tiltagende grad netop $i$ denne periode er blevet inddraget $\mathrm{i}$ behandlingen af andre sagsområder, straffelovssager.

Det reelle antal spritkørsler $\mathrm{i}$ et område har formentlig en tæt sammenhæng med forekomsten af en mere hedonistisk, traditionelt maskulint orienteret livsstil, hvor værdier som mod, umiddelbart nydelse, styrke, grænseafprøvning, oplevelser m.v. sættes i fokus. En af de mulige indikatorer på denne livsstil er på det geografiske plan antal værtshuse, ligesom alkoholforbrug og værtshuse på deres side kan befordre en sådan livsstil. Det konkrete fund i undersøgelsen er en statistisk sammenhæng mellem antal alkoholbevillinger i et område og antal spritkørsler med personskade og en tilsvarende sammenhæng mellem antal alkoholbevillinger og antal uheld med personskade, hvor sprit $i k k e$ er involveret. 


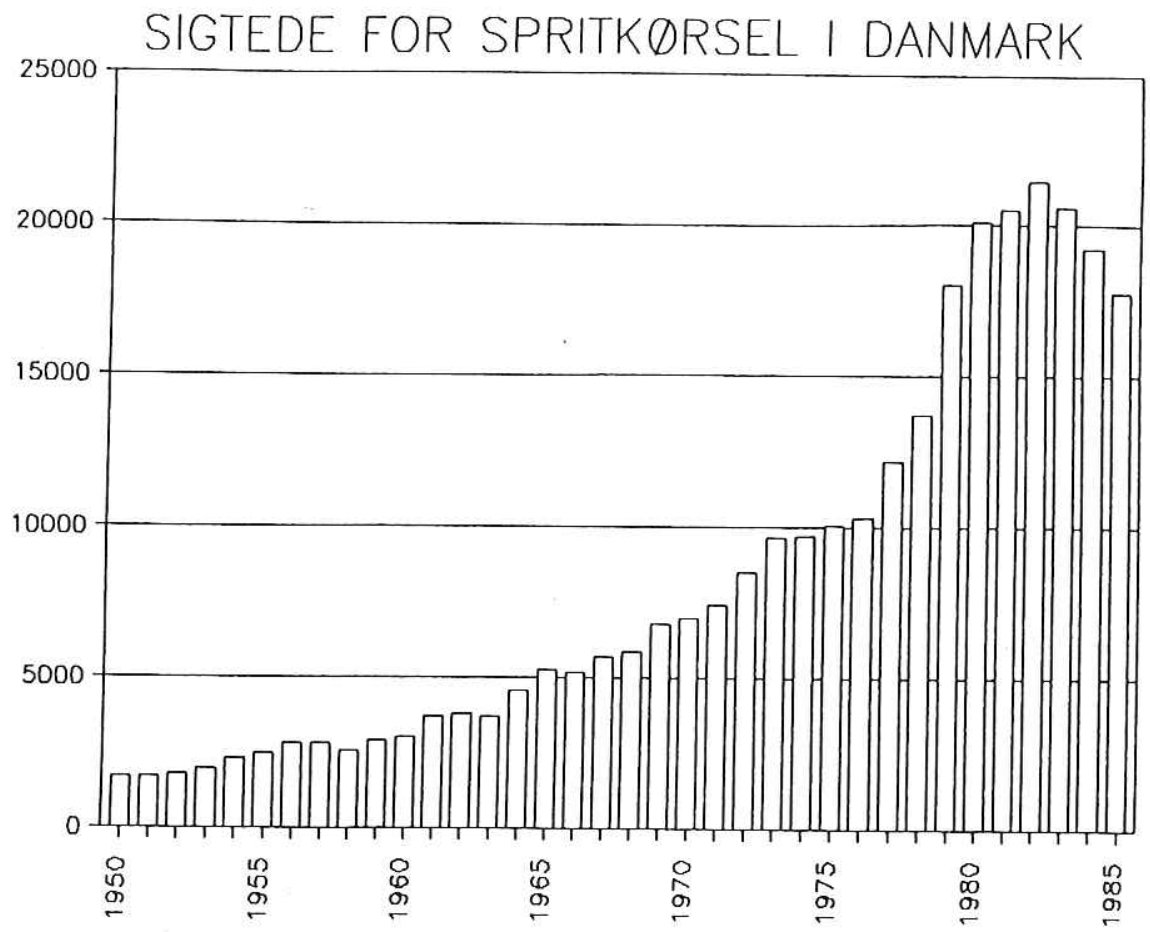

Forklaringen på det reelle fald i spritkørslernes antal fra 1982 til 1985 i Danmark kan tænkes at være en ændret livsstil - dvs. at den ovenfor omtalte livsstil har været på retur. Det er en livsstil, der traditionelt hovedsageligt bæres af unge mænd, der jo også dominerer blandt spritkørerne. Der er også andre indikationer på, at der netop blandt unge mænd er sket livsstilsforskydninger de senere år. Man har således kunnet konstatere et fald, eller i hvert fald en opbremsning, i straffelovskriminaliteten for drenge og unge mænd. Dette fald eller denne opbremsning begynder omkring samme tidspunkt som faldet i det faktiske antal spritkørsler. Mere direkte og af umiddelbar relevans er det, at det samlede alkoholforbrug netop blandt unge og yngre mænd - i modsætning til de fleste andre befolkningsgrupper - er faldet (Hansen \& Andersen, 1985). Eksempelvis tilkendegav mere end hver anden af de 17-24-årige mænd i 1977, at de drak alkohol om hverdagen. I 1985 var denne andel faldet helt ned til mindre end hver tredje. Også weekendforbruget har været faldende for yngre mænd.

I områder med få værtshuse og en mere forsagende og »langtidsorienteret« livsstil er det af betydning for den faktiske spritkørsels omfang, i hvilket omfang politiet bruger sine ressourcer på patruljering. Jo højere patruljeringsniveau, jo mindre 
spritkørsel i disse områder. En vis øgning af patruljeringen fra 1982 til 1985 synes også at have bidraget til faldet $\mathrm{i}$ antal spritkørsler.

Politistyrkens karakter indvirker således såvel - via størrelsen - på spritkørslens mørketal som - via øget patruljering - på spritkørslens faktiske omfang. Rent talmæssigt er effekten størst på mørketallet. Denne dobbelthed i kontrolfaktorens funktion vil have den overraskende, men næppe særligt ualmindelige, konsekvens, at en øget kontrolindsats i statistikken vil få det til at se ud som om, der er blevet flere spritkørsler, medens der reelt er blevet færre. Eller sat på spidsen: Der vil være en tendens til, at jo større samlede tal for spritkørsel et område udviser, jo mindre er det reelle spritkørselsproblem i området - og omvendt.

Det fremgår af analysen, at kontrolfaktoren - politipatruljeringen - og livsstilsfaktoren - værtshusforsyningen - ikke er de eneste faktorer, der påvirker spritkørslens faktiske omfang. Hvis man i en politikreds inddrog samtlige alkoholbevillinger til restauranter, værtshuse m.v., ville der ikke være grund til at vente, at niveauet ville blive meget lavere end vi nu kender det fra de store københavnske forstadskommuner. Dette viser tydeligere end andet, at omfanget af skadevoldende spritkørsler ikke kun er et spørgsmål om befolkningens mulighed for at kunne få vin til maden på de lokale restauranter eller øl på bordet på områdets værtshus. Ved en fordobling af værtshusenes antal i Danmark kan man risikere en stigning på 50\% i antal spritkørsler, men selv ved total afskaffelse af samtlige værtshuse m.v. synes man maksimalt at kunne halvere det nuværende niveau for landet som helhed. De samme forhold gør sig gældende med hensyn til tænkelige ændringer af politistyrkens størrelse og omfanget af politipatruljering. Man må dog over for disse betragtninger tage det forbehold, at sociale fænomener ofte opfører sig anderledes, når vi bevæger os ud $\mathrm{i}$ ekstremerne og uden for det område, som det egentligt har været muligt at iagttage i en undersøgelse. Eksempelvis kan alkoholbevillingernes relativt svage effekt på spritkørslernes antal i et område skyldes, at man blot i en vis udstrækning bevæger sig længere for at komme på værtshus, hvis der er få af dem - eksempelvis til nabopolitikredse. Hvis man helt afskaffede værtshuse, ville denne forskydningseffekt ikke være mulig og effekten derfor kraftigere. Selv om der i analysen har indgået et større antal variable såsom biltæthed, bebyggelseskarakter m.v., så er det ikke lykkedes at finde frem til de yderligere forhold, der er af betydning for spritkørslens omfang.

Inden man eventuelt giver sig til at skære ned på alkoholbevillingerne i Danmark og/eller sætter flere politibetjente ud på patruljering, må man gøre sig klart, at der skal ganske betydelige ændringer til i antal værtshuse og/eller politibetjente for at fremkalde mærkbare forandringer i det faktiske antal spritkørsler. Det meningsfyldte valg står mellem drastisk ændring eller ingen ændring. Dette kan illustreres ved et eksempel. Bornholm politikreds havde i 1983175 restauranter og værtshuse med alkoholbevilling, hvilket i forhold til indbyggertallet var landets højeste. Sam- 
me år sigtedes 64 for spritkørsel i forbindelse med uheld. Det er nøjagtigt det antal, man skulle forvente ud fra den generelle sammenhæng mellem alkoholbevillinger og spritkørsel, og det var også landets højeste. For at forhindre et enkelt uheld om året skal der ifølge beregningerne inddrages 5 alkoholbevillinger og 12 for at forhindre et enkelt tilfælde af spritkørsel med personskade. Efter som alene tilfældigheder vil få antallet af spritkørsler med uheld til at svinge betydeligt fra år til år - i 1982 var der 80 tilfælde på Bornholm, i 198455 - kan man se, at ændringerne i antal alkoholbevillinger skal være meget kraftige for at give et resultat, som overhovedet vil være registrerbart i en politikreds.

Det samme finder man med hensyn til antal ordensbetjente og politipatruljering. $\mathrm{Ud}$ fra de eksisterende tal for, hvad trafikulykker anses for at koste, kan man f. eks. regne sig frem til, at en patruljerende ordensbetjent gennem sin forebyggende virkning isoleret set ikke kan tjene sig selv ind. Lønomkostningerne er 6 gange større end det beløb, der spares ved færre sprituheld. Men så kan der naturligvis i tillæg også være nyttefunktioner på andre områder, ligesom man i aller højeste grad kan diskutere berettigelsen af isoleret at gøre nytteværdien op i penge.

Netop foranstaltningernes virkninger på andre områder og deres ikke-økonomiske sider må indgå i en samlet vurdering af, om man skal drage nogle praktiske konsekvenser af en undersøgelse som den gennemførte eller ej. Selv om analysens resultat således måske primært opfordrer til at skærpe opmærksomheden over for allerede udstedte og fremtidige udstedelser af alkoholbevillinger som et middel til bekæmpelse af den skadevoldende del af spritkørslen i Danmark, er det klart, at en sådan konsekvens også må vurderes i forhold til såvel den mere generelle alkoholpolitik i Danmark som det helt brede samfundspolitiske spørgsmål om, hvilke omkostninger vi er villige til at bære for nogle livsmuligheder, som også giver en masse positive oplevelser. Man forbyder jo heller ikke uden videre udstilling af moderne kunst, ægte tæpper m.v., selv om man ved, at disse udstillinger og deres salg øger muligheden for lukrative investeringer af sorte penge.

På det helt praktiske plan er det dog væsentligt at holde fast ved, at spritkørsel synes at være en form for kriminalitet som - i modsætning til mange andre kriminalitetsformer - direkte synes at kunne påvirkes af omfanget af for befolkningen synlig politipatruljering. En direkte manifestation af dette er også den nedbringelse af spritkørsler i forbindelse med juleperioden, som en intensiveret politiindsats - og en omfattende pressemæssig dækning af denne - har haft i Danmark. En nærmere tilrettelæggelse af patruljeringen i de enkelte politikredse i perspektiv af omfanget og karakteren af områdets værtshuse - $\mathrm{i}$ øjeblikket er der ingen sammenhæng - indeholder visse præventive muligheder med hensyn til spritkørsel, og måske også gadevold og værtshusvold. Eller for at være helt konkret: Når nu politibilen skal placeres et sted er området omkring værtshusenes ind- og udgangspartier næppe det dårligst tænkelige. 


\section{LITTERATUR}

Andenaes, J.: The Effects of Scandinavia's Drinking-and-Driving Laws, i Drinking and Driving in Scandinavia. Scandinavian Studies in Criminology, volume 6. Oslo: Universitetsforlaget, 1978, ss. 35-54.

Balvig, F. m.fl.: Gadevold. København: Det kriminalpræventive Råd, 1986.

Begeer, W.: One hundred years of penal code in the Netherlands: a statistical view of 18861986. The Hague: Netherlands Central Bureau of Statistics, 1986.

Bunce, R. m.fl.: California's Alcohol Experience: Stable Patterns and Shifting Responses, i Single, E. m.fl. (red.): Alcohol, Society, and the State. 2. The social History of Control Policy in seven Countries. Toronto: Addiction Research Foundation, 1981.

Dalgaard, J. B. m.fl.: Drcebt i bil. Ulykkesårsager og selevirkning. En trafikmedicinsk undersøgelse. Rapport 21. Århus: Retsmedicinsk Institut Ảrhus \& Rådet for Trafiksikkerhedsforskning, 1977.

Dalgaard, J. B.: Alkohol som risikofaktor i trafikken, i Alkohol og trafik. Material från alkoholforskningsseminarier arrangerade av Nordiska Nämnden för alkoholforskning. Stockholm: Nordiska Nämnden för alkoholforskning, 1978.

Greve, V.: Studier i fcerdselsstrafferet. København: Juristforbundets Forlag, 1979.

Hansen, E. J. \& Andersen, D.: Alkoholforbrug og alkoholpolitik. Publikation 145, København: Socialforskningsinstituttet, 1985.

Koch, H.: Politipatruljering og spritkørsel. Tidsskrift for Dansk Politi, 1979, ss. 344-348.

Nielsen, K.: Spritbilisters sociale problemer - en undersøgelse blandt afsonere af spritdomme, efteråret 1976. København: Kontaktudvalget vedrørende alkohol-og narkotikaspørgsmål, 1978.

Nielsen, J. m.fl.: En geografisk analyse af voldsofres bopal og skadested for vold, i Hedeboe, J. (red.): Vold i Árhus. En rapport om voldsulykker $i$ Ärhus gennem et år. Århus: FADLs Forlag, 1984.

Single, E. M. fl.: The Alcohol Policy Debate in Ontario in the Postwar Era, i Single, E. m.fl. (red.): Alcohol, Society, and the State. 2. The Social History of Control Policy in seven Countries. Toronto: Addiction Research Foundation, 1981.

Votey, H. L.: The Deterrence of Drunken Driving in Norway and Sweden: An Econometric Analysis of Existing Policies, i Drinking-and-Driving in Scandinavia. Scandinavian Studies in Criminology, volume 6. Oslo: Universitetsforlaget, 1978, ss. 79-100.

Walsh, D. \& Walsh, B.: Alcohol and Drinking in Ireland in the Post-War Period, i Single, E. m.fl. (red.): Alcohol, Society, and the State. 2. the Social History of Control Policy in seven Countries. Toronto: Addiction Research Foundation, 1981.

Waage, N.: Spritkørsel. Sager om spiritus- og promillekørsel. København: Gad, 1985.

Adr.: $\quad$ Lektor, mag. scient. soc. Flemming Balvig

Kriminalistisk Institut

Københavns Universitet

Sct. Peders Stræde 19

DK-1453 København K

TIf. 01912166 